\title{
Participatory market chain appraisal for the full range of agroforestry products including market trends and growing markets
}

\author{
S. M. Amatya ${ }^{1 *}$, I. Nuberg ${ }^{2}$, E. Cedamon ${ }^{2}$, K. K. Shrestha ${ }^{3}$, B. H. Pandit ${ }^{1}$, \\ P. Aulia ${ }^{4}$, M. Joshi $^{1}$ and B. Dhakal ${ }^{1}$
}

This paper focuses on the participatory market chain analysis of agroforestry products in six sites of two districts (Kavre and Lamjung) of Nepal. In total, 93 market actors were involved in the study, in which 80 persons were purposively selected from Local Resource Person (LRP) and Local Resource Group (LRG) members and 13 persons were randomly selected from the local, district and national level traders. Primary data on agroforestry products was collected through Participatory Rural Appraisal (PRA) tools following several field visits. Fourteen agroforestry products in Lamjung and 20 agroforestry products in Kavrepalanchok district were selected for analysis. The findings showed that small-scale production and insufficient service to farmers from the village level agriculture collection centers and cooperatives are the major constraints to effective and efficient market chain development and management. The main factors responsible for increasing the production of agroforestry products are the rise in awareness among LRPs/ LRGs about agroforestry practices along with institutional and policy development to facilitate the marketing of agroforestry products. The paper concludes by highlighting the controlling factors in agroforestry business.

Key words: Agroforestry market chain, agroforestry products, market trend, participatory appraisal

$\mathrm{N}^{\text {sits }}$ epal's food insecurity is worsening as traditional agroforestry systems being practiced are unable to adapt to, or make use of, changing market and climatic conditions. Improving the agroforestry practice aside, one of the ways to improve food security is to enhance agroforestry marketing practices. Agroforestry product marketing is a dynamic and complicated process, which covers various activities and agencies from producers to the consumers (Amatya et al., 2015). One of the main problems of agroforestry product marketing in Nepal is small scale production resulting in low productivity in volume and quality (Pandit et al., 2014). Sustainable marketing mechanism differs with the location and available infrastructures. The market chain and trends of all agroforestry products produced in research sites are not known. Therefore, a study was undertaken to

identify the existing market mechanism for agroforestry products of the project research sites, to assess the market chain of the full range of agroforestry products harvested and to explore the factors responsible for changing agroforestry products market chain and trends, its barriers and constraints, opportunities and limitations.

\section{Materials and methods}

In order to investigate food security and livelihoods of rural people, a five year joint project of Government of Nepal and Australian Government is being implemented in six sites of two districts (Kavre and Lamjung) in Nepal since 2013. The market mechanisms were looked at involving project beneficiaries categorised as Local Resource Persons (LRPs) and Local Resource Groups (LRGs) who are also the

1 Nepal Agroforestry Foundation, Kathmandu, Nepal.*E-mail: swoyambhu_amatya@yahoo.com

2 Professor, University of Adelaide, Australia

3 Professor, University of New South Wales, Australia

4 International Centre for Research in Agroforestry, Indonesia 
members of six Community Forest User Groups of the case study districts. Various agroforestry products related with primary food security such as vegetables, fruits, spices, flowers and timber products were grown by these LRPs/ LRGs' in their fields. These groups developed various types of marketing mechanisms to overcome some of the constraints of small-scale agroforestry products.

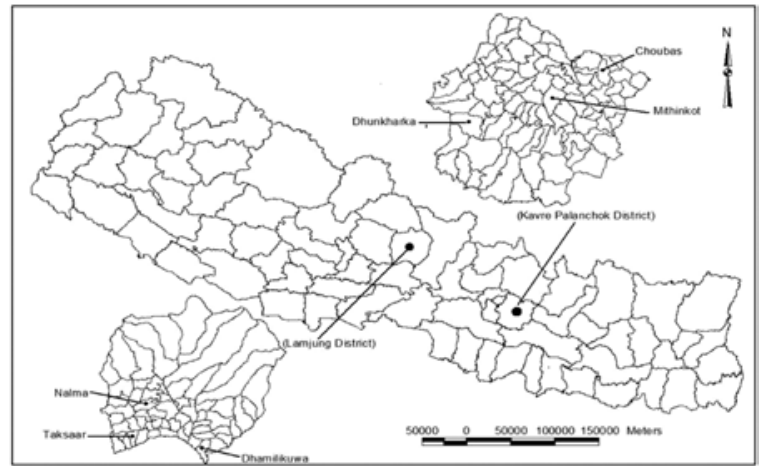

Fig. 1: Location of study area

This study adopted a descriptive qualitative case study approach to obtain an in-depth analysis of context in which agroforestry market chain occurs. It also employed quantitative methods to analyse the quantity and price of the products related to the benefits gained by different social actors along the market chain. The qualitative strategy is aimed to generate insights into the processes and practice through which the agroforestry product market chains are organised. Emphasis is given to the analysis of behaviours of market actors. The quantitative strategy complements qualitative analysis by brining insights of the distribution of benefit from agroforestry product trade.

A commodity selection process was conducted to identify the most promising market options (Ostertag et al., 2007). Thirty-seven commodities were selected in the beginning from six sites: Dhungkharka, Mithinkot, and Chaubas in Kavre, Dhamilikuwa, Jeeta Taksar, and Nalma in Lamjung (NAF, 2014). This framework was developed based on three criteria as described below:

Step 1 Selection criteria: The value chains were evaluated in focus group discussion using seven criteria: a) market and market demand b) economy of scale and outreach c) high value d) stakeholders' interest and commitment (women and poorest households) e) coordination f) short turnover and g) leverage.

Step 2 Weightage percentage: The first criteria 'market and market demand' was given $20 \%$ weightage, the second to fifth criteria were given $15 \%$ and the rest two were given $10 \%$ weightage each.

Step 3 Assessing commodities fit against each criterion: Each criterion was given a score in a range from 1 to 5 , with 5 representing maximum compliance and 1 minimum compliance. Overall ranking was determined using a weighted average of the seven criteria.

Primary information regarding products, market chain, trends and market growth were collected through field visits using Participatory Rural Appraisal (PRA) tools and technique and review of literatures. Information was also collected through key informants' interview and focus group discussion. Discussions were also held with CFUG (Community Forestry Users Groups) executive committee members, LRPs, local teachers, and government line agencies supporting LRPs and LRGs members for agroforestry intervention in the project sites and traders of agroforestry products. Information required for the analysis of the agroforestry products, data on prices and costs were collected at successive levels of the market chain. To identify the market actors involved in the market chain, a snowball sampling method (Hair et al., 2010) was used. The direction of the snowballing approach was from farmers to consumers. The researchers participated directly in the marketplace. They were able to describe the market chain due to their direct participation and observation of marketing places of agroforestry products at the local, district and national level, they were able to describe the market chain. Initially, information was collected from farmers who helped to identify the traders. Subsequently, the identified traders were approached for the necessary information as well as for identification of other traders and cooperation to who they sold the products.

To analyse the overall agroforestry product market chain, Rapid Market Appraisal (RMA) was used to identify and assess the problems and opportunities related to the market system and to understand how the trade is organized, operates 
and performs. As an iterative process and interactive research methodology, RMA was used to better understand complex market systems in a short time (ILO, 2000; Ostertag et al., 2007; Perdana et al., 2013) using in-depth interviews and focus group discussions.

Secondary information of agroforestry products market chain and their trend and marketing mechanisms, and their barriers and constraints, opportunities and limitations were gathered to supplement primary data. The main source of secondary data were LRP and LRG member's records and reports of other line agencies and traders, agroforestry markets and marketing mechanisms, and related published and unpublished documents, literatures and journals. Key agriculture and forestry related policy documents were also reviewed to understand the market chain of agroforestry products and change over market chain actors and price of agroforestry products at the local, district and national level.
In total 93 market actors were involved in the study, in which 80 persons were purposively selected from LRP and LRG members and 13 persons were randomly selected from the local, district and national level traders. The participation of women in this study was $43 \%$. Among 93 respondents only $10 \%$ were Dalits, $50 \%$ were from ethnic community and $40 \%$ were Brahmin and Chhetri. In the study population, agriculture, business and services were found major occupation. Out of them, majority $(80 \%)$ of the total respondents were dependent mainly on agriculture based occupation.

\section{Results and discussion}

A total of 16 commodities were selected in the first phase which received at least the score of good compliance (Table 1). In the second phase, the high scoring (maximum compliance) commodities such as buffalo milk, goat meat, banana, tomato, cardamom, ginger and round chillies were selected which scored more than four.

Table 1: Result of agroforestry commodity selection process

\begin{tabular}{|c|c|c|c|c|c|c|}
\hline \multirow[b]{2}{*}{ Commodity name } & \multicolumn{3}{|l|}{ Kavre } & \multicolumn{3}{|l|}{ Lamjung } \\
\hline & $\begin{array}{l}\text { Dhung } \\
\text { kharka }\end{array}$ & Mithinkot & Chaubas & $\begin{array}{l}\text { Dhamili } \\
\text { kuwa }\end{array}$ & $\begin{array}{l}\text { Jeeta } \\
\text { Takshar }\end{array}$ & Nalma \\
\hline 1. Buffalo milk & $\sqrt{ } \sqrt{ } \sqrt{ }$ & $\sqrt{ } \sqrt{ } \sqrt{ }$ & $\sqrt{ } \sqrt{ } \sqrt{ }$ & $\sqrt{ } \sqrt{ } \sqrt{ }$ & $\sqrt{ } \sqrt{ }$ & $\sqrt{ }$ \\
\hline 2. Goat meat & $\sqrt{ } \sqrt{ } \sqrt{ }$ & $\sqrt{ } \sqrt{ } \sqrt{ }$ & $\sqrt{ } \sqrt{ } \sqrt{ }$ & $\sqrt{ } \sqrt{ } \sqrt{ }$ & $\sqrt{ } \sqrt{ } \sqrt{ } \sqrt{ }$ & $\sqrt{ } \sqrt{ } \sqrt{ }$ \\
\hline 3. Timber & $\sqrt{ } \sqrt{ }$ & $\sqrt{ }$ & $\sqrt{ } \sqrt{ } \sqrt{ }$ & $\sqrt{ }$ & $\sqrt{ }$ & $\sqrt{ }$ \\
\hline 4. Lauth salla & $\sqrt{ } \sqrt{ } \sqrt{ }$ & $\mathrm{x}$ & $\sqrt{ } \sqrt{ }$ & $\mathrm{x}$ & $x$ & $\mathrm{x}$ \\
\hline 5. Brooms & $\sqrt{ } \sqrt{ }$ & $\sqrt{ }$ & $\sqrt{ } \sqrt{ }$ & $\sqrt{ }$ & $\sqrt{ } \sqrt{ } \sqrt{ }$ & $\sqrt{ } \sqrt{ } \sqrt{ }$ \\
\hline 6. Ginger & $\mathrm{x}$ & $\sqrt{ } \sqrt{ } \sqrt{ } \sqrt{ }$ & $\mathrm{x}$ & $\sqrt{ }$ & $\sqrt{ }$ & $\mathrm{x}$ \\
\hline 7. Lapsi & $\sqrt{ }$ & $\sqrt{ }$ & $\sqrt{ } \sqrt{ }$ & $\mathrm{x}$ & $\sqrt{ }$ & $\sqrt{ } \sqrt{ } \sqrt{ }$ \\
\hline 8. Cardamom & $\sqrt{ } \sqrt{ }$ & $\mathrm{x}$ & $\sqrt{ } \sqrt{ } \sqrt{ }$ & $\mathrm{x}$ & $\mathrm{x}$ & $\sqrt{ } \sqrt{ }$ \\
\hline 9. Banana & $\mathrm{x}$ & $\sqrt{ }$ & $\mathrm{x}$ & $\sqrt{\sqrt{ } \sqrt{ }}$ & $\sqrt{ } \sqrt{ } \sqrt{ }$ & $\sqrt{ } \sqrt{ }$ \\
\hline 10. Honey & $\sqrt{ }$ & $\sqrt{ }$ & $\sqrt{ }$ & $\sqrt{ }$ & $\sqrt{ } \sqrt{ } \sqrt{ }$ & $\sqrt{ }$ \\
\hline 11. Bamboo & $\mathrm{x}$ & $\sqrt{ }$ & $\mathrm{x}$ & $\sqrt{ }$ & $\sqrt{ } \sqrt{ } \sqrt{ }$ & $\mathrm{x}$ \\
\hline 12. Drum stick & $\mathrm{x}$ & $\mathrm{x}$ & $\mathrm{x}$ & $\sqrt{ } \sqrt{ }$ & $\sqrt{ }$ & $\mathrm{x}$ \\
\hline 13. Round chilli & $\mathrm{x}$ & $\sqrt{ } \sqrt{ } \sqrt{ }$ & $\mathrm{x}$ & $\mathrm{x}$ & $\sqrt{ }$ & $\sqrt{ } \sqrt{ } \sqrt{ }$ \\
\hline 14. Tomato & $\sqrt{ } \sqrt{ } \sqrt{ }$ & $\mathrm{x}$ & $\sqrt{ } \sqrt{ } \sqrt{ }$ & $\mathrm{x}$ & $\mathrm{x}$ & $\sqrt{ } \sqrt{ }$ \\
\hline 15. Tejpat & $\sqrt{ } \sqrt{ }$ & $\sqrt{ }$ & $\sqrt{ }$ & $\sqrt{ } \sqrt{ } \sqrt{ }$ & $\sqrt{ } \sqrt{ } \sqrt{ }$ & $\sqrt{ } \sqrt{ }$ \\
\hline 16. Satawari/Kurilo & $\mathrm{x}$ & $\sqrt{ } \sqrt{ } \sqrt{ }$ & $\sqrt{ }$ & $\sqrt{ }$ & $\sqrt{ }$ & $\sqrt{ }$ \\
\hline $\begin{array}{l}\text { Number of } \\
\text { products selected }\end{array}$ & 5 & 5 & 5 & 5 & 6 & 4 \\
\hline
\end{tabular}

Scale: $\mathrm{x}$ - no compliance $(0$ score $) ; \sqrt{ }$ - little compliance $(1-2$ score $) ; \sqrt{ } \sqrt{ }$ - compliance $(2-3$ score $)$; $\sqrt{ } \sqrt{ }$ - good compliance $(3-4$ score $) ; \sqrt{ } \sqrt{ } \sqrt{ }$ - max compliance $(4-5$ score). 
At least one maximum compliance agroforestry product was thus selected from each of the six sites. These included tomato from Dhungkharka, ginger from Mithinkot, cardamom from Chaubas, round chilli from Nalma and banana from two sites (Jeeta Taksar and Dhamilikuwa) in the beginning (Fig. 1).

As identified through research, producers, collectors, retailers, and cooperatives were the major actors in the market chain in the study areas. The following section describes their roles and practices in the market chain prices at different market levels, and the growing markets of agroforestry products.

\section{Producers}

Farmers involved in producing agroforestry products were the main producers. Producers in the study areas tended to sell what was produced and did not engage in further processing or value adding activities. Generally, they were producing vegetables and other products in small quantity, and then these products were collected by collectors in one place through a group of farmers or cooperatives and delivered to wholesalers in Kathmandu valley (Table 2). They had engaged in the market chain mostly through collectors and retailers, but generally they had limited access to market information and were seldom in a position to negotiate higher rates. Regardless of the negotiation approach taken, producers usually perceived that their products were bought at a price that was lower than expected because of their limited access to market information, weak bargaining position, and the dominant role of traders. Their current practice is limited on small scale production resulting in low productivity in terms of volume and quality (Pandit et al., 2014).

\section{Collectors, wholesalers, and retailers}

Collectors play an important role in the agroforestry product market chain. First, they search for potential buyers in the marketplace and enquire as to the buyers' requests. Guided by their information network, they visit smallholders, searching for products available for harvest, which suit the request. They also explore upstream to increase their supply. They repeat this process frequently because supply, quality, and prices change so often. Second, the harvest of multiple producers is sorted into lots for sale to the wholesalers and retailers. Third, they serve to minimise and facilitate the number of contacts in the market chain.

Competition between other collectors was mostly from neighbouring villages. They had access to market information such as current prices, demands and specifications. From their informants, the collectors were aware of prices offered by other collectors. Their role ended when the products were delivered to the buyers, wholesalers or retailers.

Wholesalers are the middle traders who purchase products in huge amounts at significant discounts from collectors or agriculture products marketing cooperatives, and then distributed among the retailers at higher prices. On an average wholesaler in Kathmandu received 13-17\% benefits from their marketing activities.

Retailers were town or city based traders who had bought agroforestry products from collectors. They had well-established contacts with most collectors in the study area, as they had been engaged in an extensive business relationship for some time. Similar to the relationship between producers and collectors, links with larger traders were a matter of mutual trust built upon a gradually established relationship. The retailers had purchased agroforestry products from the wholesalers and sold to the end users at a marked up price. The best example of a retailer would be the small family-operated fruit shop on the corner of a market, hotels and supermarkets. On an average, retailers in Kathmandu received $20-25 \%$ benefits from agroforestry products marketing. 
Table 2: List of agroforestry products in the study area

\begin{tabular}{|l|l|l|l|}
\hline Study site & $\begin{array}{l}\text { Agroforestry } \\
\text { products }\end{array}$ & Study site & Agroforestry products \\
\hline \multicolumn{2}{|c|}{ Lamjung } & \multicolumn{2}{|c|}{ Kavre } \\
\hline \multirow{2}{*}{$\begin{array}{l}\text { Aapchaur CFUG, } \\
\text { Dhamilikuwa }\end{array}$} & $\begin{array}{l}\text { Banana } \\
\text { Cauliflower Potato } \\
\text { Tomato } \\
\text { Black pepper } \\
\text { Milk }\end{array}$ & $\begin{array}{l}\text { Kalapani CFUG, } \\
\text { Dhungkharka }\end{array}$ & $\begin{array}{l}\text { Cabbage Cauliflower Potato } \\
\text { Mustard leaves } \\
\text { Radish } \\
\text { Garlic } \\
\text { Milk }\end{array}$ \\
\hline $\begin{array}{l}\text { Lampata CFUG, Jeeta } \\
\text { Taksar }\end{array}$ & $\begin{array}{l}\text { Banana } \\
\text { Ginger } \\
\text { Turmeric Honey } \\
\text { Broom grass } \\
\text { Sugarcane }\end{array}$ & $\begin{array}{l}\text { Cardamom } \\
\text { Pumpkin } \\
\text { Marigold flower Lapsi }\end{array}$ \\
\hline $\begin{array}{l}\text { Khundru Langdi CFUG, } \\
\text { Nalma }\end{array}$ & $\begin{array}{l}\text { Round chilly } \\
\text { Potato } \\
\text { Tomato Onion Goat }\end{array}$ & $\begin{array}{l}\text { Sa Pa Ru Pa } \\
\text { CFUG, } \\
\text { Methingkot }\end{array}$ & $\begin{array}{l}\text { Ginger } \\
\text { Chilly } \\
\text { Pine timber }\end{array}$ \\
\hline
\end{tabular}

\section{Aapchaur CFUG of Dhamilikuwa, Lamjung}

The main agroforestry products marketed from the Dhamilikuwa of Lamjung district were banana, black pepper, milk, cauliflower, potato and tomato. These products were sold in local markets located in the district through three market actors (producers, retailers and consumers). The major constraints of this marketing mechanism were price variation due to the lack of information and services in the local market, lack of storage facilities. In addition, they also lacked skill and knowledge on quality and value enhancement through grading and processing. However, the development of road transportation system in the village and telephone communication has helped farmers significantly for marketing of their agroforestry products. Producers and retailers of local markets had known very well with each other and had mobile telephone communication facilities to plan and organize agroforestry product marketing in this action research test site.

Farmers of Dhamilikuwa were selling their fresh products directly to the retailers of surrounding township such as Bhoteodar, Sundar bazaar, Besisahar and other local markets, which are located in nearly one hour driving distances from Dhamilikuwa. Retailers have contact directly to the farmers by telephone and then farmers supplied their fruits and vegetables based on demand of these retailers. Farmers harvest their products, clean it in fresh water and then packet in plastic bags and send to the retail markets. Figure 2 shows the agroforestry products marketing mechanisms of Dhamilikuwa.

Fig. 2: Market chain of agroforestry products of Dhamilikuwa

Retailers were also selling these products to consumers without any value addition work. In this site, the "Radha Krishna Agriculture Cooperative" was found passive due to low volume of agriculture products.

The production capacity of these traded agroforestry products (Table 3) of Dhamilikuwa site was found high because there was very good irrigation facilities compared with other five action research sites. The number of farmers, land areas and per unit production have been increased compared with 3 years ago. The main factors responsible for the increment were awareness raising in agroforestry by the project team and developing institution of LRGs and LRPs. In addition, farmers were also diverted into cash crops. The price of agroforestry products at local market was also increased by $15 \%$ compared 
Table 3: Agroforestry products, their quantity and per unit price at different markets

\begin{tabular}{|l|l|l|l|l|}
\hline \multirow{2}{*}{$\begin{array}{l}\text { Agroforestry } \\
\text { products }\end{array}$} & \multirow{2}{*}{$\begin{array}{l}\text { Approximate } \\
\text { production quantity }\end{array}$} & \multicolumn{3}{|l|}{ Price (Rs) at different level of markets } \\
\cline { 3 - 5 } & & Farm gate (local) & District & National \\
\hline Banana & 25000 darjan & $40 /$ darjan & $65 /$ darjan & $80 /$ darjan \\
\hline Cauliflower & $5000 \mathrm{~kg}$ & $45 / \mathrm{kg}$ & $55 / \mathrm{kg}$ & $60 / \mathrm{kg}$ \\
\hline Potato & $6000 \mathrm{~kg}$ & $40 / \mathrm{kg}$ & $50 / \mathrm{kg}$ & $55 / \mathrm{kg}$ \\
\hline Tomato & $3000 \mathrm{~kg}$ & $50 / \mathrm{kg}$ & $65 / \mathrm{kg}$ & $75 / \mathrm{kg}$ \\
\hline Black pepper & $50 \mathrm{~kg}$ & $800 / \mathrm{kg}$ & $1200 / \mathrm{kg}$ & $1400 / \mathrm{kg}$ \\
\hline Milk & 50000 litres & $40 /$ litre & $60 /$ litre & $65 /$ litre \\
\hline
\end{tabular}

Note: 1 darjan $=12$ banana

with three years ago. However, low volume of production was the major constraint for developing and managing agroforestry product marketing mechanism in this site.

Table 3 shows that price difference of banana between farm gate price, local/district markets and national markets. The price of banana at national market was very high compared with other agroforestry products. Farmers of this site were using chemical fertilizers such as Di-ammonium phosphate, urea and muriate of potash, etc to produce rice, maize, wheat, potato, tomato and cauliflower, etc. The use of chemical fertilizers ranged from $25-150 \mathrm{~kg}$ per households, which cost Rs 45/kg. In addition, some farmers also had used insecticides such as Novan to protect potato and tomato crops from fungal diseases. More chemical fertilizers were used in cereal crops compared with vegetable crops. The average total cost of production of marketable agroforestry products such as cauliflower, potato and tomato was calculated Rs 30 per kg. Agroforestry products of the test site were sold in local level markets, and therefore, load, unload and transportation costs up to the local markets was only Rs $2-3$ per kg.

\section{Lampata CFUG of Jeeta Taksar, Lamjung}

The major agroforestry products marketed from the Jeeta Taksar site were banana, ginger, turmeric, broom, honey and black sugarcane. These products were sold in local markets through three market actors (producers, retailers and consumers). There was lack of market information and services in the local market. In addition, they did not have storage and transportation facilities. They also lacked skill and knowledge on quality and value addition through grading and processing. Development of road transportation system in the village had helped them significantly for marketing of their agroforestry products. Banana farmers had harvested their products targeting to festival and other local level religious functions.

Local fruit sellers and retail shop keepers of local market, called Sotipasal, had direct contact with farmers or producers, and farmers supplied their banana fruits and other fresh products based on demand of fruit sellers and shop keepers. Farmers harvest their products, clean it in fresh water and then delivered to the markets. Figure 3 shows the agroforestry products marketing mechanisms of Jeeta Taksar site.

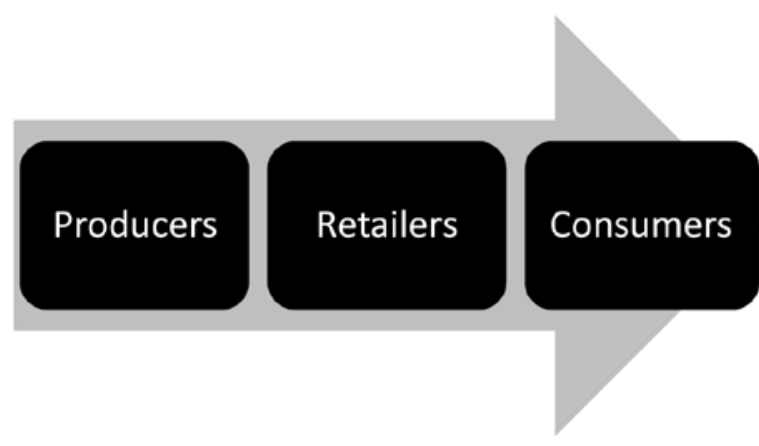

Fig. 3: Market chain of agroforestry products of Jeeta Taksar site

The production capacity of traded agroforestry products (Table 4) of this site can be improved in coming years because there are increasing trend in number of farmers, land areas, per unit production and price of agroforestry products 
Table 4: Agroforestry products, their quantity and per unit price at different markets

\begin{tabular}{|l|l|l|l|l|}
\hline \multirow{2}{*}{$\begin{array}{l}\text { Agroforestry } \\
\text { products }\end{array}$} & \multirow{2}{*}{$\begin{array}{l}\text { Approximate } \\
\text { quantity }\end{array}$} & \multicolumn{3}{|l|}{ Price (Rs/unit) at different level of markets } \\
\cline { 3 - 5 } & 20,000 darjan & Farm gate (local) & District & National \\
\hline Banana & $2500 \mathrm{~kg}$ & $20 / \mathrm{kg}$ & $60 /$ darjan & $100 /$ darjan \\
\hline Ginger & $800 \mathrm{~kg}$ & $100 / \mathrm{kg}$ & $60 / \mathrm{kg}$ & $95 / \mathrm{kg}$ \\
\hline Turmeric & $800 \mathrm{mana}$ & $600 /$ mana & $140 / \mathrm{kg}$ & $160 / \mathrm{kg}$ \\
\hline Honey & $600-800 \mathrm{kucho}$ & $30 /$ kucho & $650 / \mathrm{mana}$ & $750 / \mathrm{mana}$ \\
\hline Broom grass & 3500 sugarcane & $45 /$ sugarcane & $40 /$ kucho & $40 /$ kucho \\
\hline Sugarcane & & & $65 /$ sugarcane & $80 /$ sugarcane \\
\hline
\end{tabular}

Note: 1 mana=568 $\mathrm{ml}$ (approximately) Kucho is made from broom grass

compared with three years ago. The main factors responsible for increasing agroforestry production were increase in awareness level. However, farmers were facing problem in selling ginger. A product collection centre was established in 2012 for marketing of agriculture products, which was found passive due to the low production of agriculture commodities.

Table 4 shows that price difference of banana and ginger between farm gate price, local markets, district markets and national markets was very high compared with other agroforestry products marketed from this test sites.

Farmers of these sites were using Di-ammonium phosphate and urea mainly in rice field and some farmers were also found using chemical fertilizers in vegetable farms. The use of chemical fertilizers ranged from $5-25 \mathrm{~kg}$ per household, which cost Rs $47 / \mathrm{kg}$. In addition, some farmers were also using insecticides in rice field. The use of chemical fertilizers and insecticides in marketable agroforestry products were nominal, and transportation cost was not required because almost all agroforestry products were sold in local markets.

\section{Khundru Langdi CFUG of Nalma, Lamjung}

The main marketable agroforestry products of Nalma site were round chilly, potato, tomato, onions and goat production. These products were sold locally moving through producers to consumers because the productions were very low compared with local demands. There was lack of market information and services in the local market. They also lacked skill and knowledge on quality and value addition through grading and processing.

Agroforestry products such as round chilly, potato, tomato and onion were sold in local markets, while farmer had kept goat for meat production but there was no organized way of selling them in market. Local and district level contractors visit the households having goats, and buy them to supply in district level markets. One saving and credit institution and mother group were found functioning in this test site but they were not taking any care of agroforestry products marketing because production quantity was very low and the consumption was within the village.

The production capacity of traded agroforestry products is provided in table 5 . It was revealed that trend of agroforestry marketing was increasing as compared with three years ago. The main factors responsible for increase in agroforestry production are the increase in the level of awareness and development of institutional capacity of LRG and LRP.

Table 5 shows that price of agroforestry products such as potato, tomato and onion in Nalma was higher than the price of these products in district and national level markets. This could be the effect of attribute to the high demand of these products compared with local level production. 
Table 5: Agroforestry products, their quantity and per unit price at different markets

\begin{tabular}{|l|l|l|l|l|}
\hline \multirow{2}{*}{$\begin{array}{l}\text { Agroforestry } \\
\text { products }\end{array}$} & \multirow{2}{*}{ Approximate quantity } & \multicolumn{3}{|l|}{ Price (Rs/kg) at different level of markets } \\
\cline { 3 - 5 } & & Farm gate (Local) & District & National \\
\hline Round chilly & $60 \mathrm{~kg}$ & $250 / \mathrm{kg}$ & 300 & $350-400$ \\
\hline Potato & $1000 \mathrm{~kg}$ & $60 / \mathrm{kg}$ & 40 & 55 \\
\hline Tomato & $900 \mathrm{~kg}$ & $70 / \mathrm{kg}$ & 65 & 75 \\
\hline Onion & $600 \mathrm{~kg}$ & $60 / \mathrm{kg}$ & 45 & 50 \\
\hline Goat & 50 goats & $400 / \mathrm{kg}$ of meat & 700 & 800 \\
\hline
\end{tabular}

Majority $(60 \%)$ of the farmers were producing organic products and those farmers, who were using chemical fertilizers, had used in low volume. The average cost of chemical fertilizer is Rs 52/ $\mathrm{kg}$. The average cost of production of round chilly, potato, tomato and onion was Rs 35 per $\mathrm{kg}$, and these products were sold in local village.

\section{Sa Pa Ru Pa CFUG of Methingkot, Kavrepalanchok}

The main agroforestry products sold by the LRP and LRG members from the Methinkot research sites were ginger, chilly, tomato, milk and goat. Beside these, different kinds of vegetables such as potato, cauliflower, cabbage, radish, pumpkin, cucumber, etc were also sold by the CFUG members. Agroforestry market chain is from producers to consumers through collectors and retailers. Producers lacked price information, and knowledge on quality and value enhancement through grading and processing.

Local traders and traders of Banepa and Kathmandu valley also visit Bhakundebesi market to purchase ginger and other vegetables, and goats, which is $2 \mathrm{~km}$ far from this site. There is one agriculture co-operative, which is also involved in ginger marketing. Figure 4 shows the agroforestry products marketing mechanisms of Methinkot site.

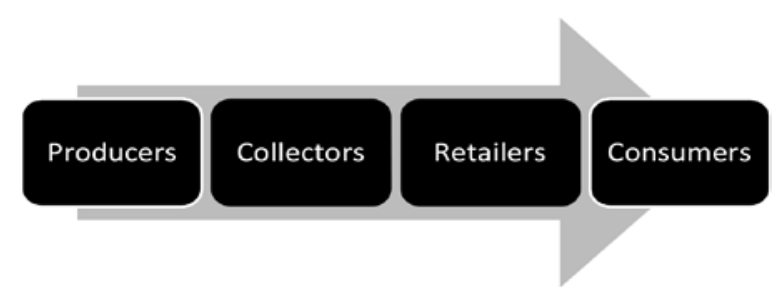

Fig. 4: Market chain of agroforestry products of Methinkot test site

Change in rainfall pattern and lack of irrigation facilities have hindered the cultivation of agroforestry products (Table 6). However, there is increasing trend in number of farmers, land areas and price of agroforestry products compared with three years ago due to increase in the awareness level of participating farmers.

This site is near to Kathmandu market, but farmers were getting nearly $47 \%$ low prices compared with national market price. Farmers of Methinkot sites were forced to sell their products in low price compared with national markets.

Table 6: Agroforestry products, their quantity and per unit price at different markets

\begin{tabular}{|l|l|l|l|l|}
\hline \multirow{2}{*}{$\begin{array}{l}\text { Agroforestry } \\
\text { products }\end{array}$} & \multirow{2}{*}{$\begin{array}{l}\text { Approximate } \\
\text { quantity }\end{array}$} & \multicolumn{3}{|l|}{ Price (Rs/unit) at different level of markets } \\
\cline { 3 - 5 } & Farm gate (Local) & District & National \\
\hline Ginger & $4000 \mathrm{~kg}$ & $65 / \mathrm{kg}$ & $75 / \mathrm{kg}$ & $100 / \mathrm{kg}$ \\
\hline Chilly & $2500 \mathrm{~kg}$ & $75 / \mathrm{kg}$ & $100 / \mathrm{kg}$ & $125 / \mathrm{kg}$ \\
\hline Tomato & $30000 \mathrm{~kg}$ & $30 / \mathrm{kg}$ & $40 / \mathrm{kg}$ & $55 / \mathrm{kg}$ \\
\hline Milk & 72000 litre & $65 /$ litre with fat & $65 /$ litre & $65 / \mathrm{litre}$ \\
\hline Goat & 150 goats & 400 per kg of meat & $700 / \mathrm{kg}$ & $800 / \mathrm{kg}$ \\
\hline
\end{tabular}


Farmers of Methinkot sites had used chemical fertilizers (Di-ammonium phosphate and urea) ranging from $25-200 \mathrm{~kg}$ per household, which cost Rs 40 per kg. Insecticides were also being used in vegetable farms. The average cost of production of tomato was calculated at the rate of Rs 25 per $\mathrm{kg}$. The transportation cost of vegetables from this research sites to Banepa was about Rs 2 per kg.

\section{Kalapani CFUG of Dhungkharka, Kavre}

The main agroforestry products of Dhungkharka site were tomato grown in plastic tunnel during off-season and main season, cauliflower, cabbage, mustard leaves, chilli, potato, radish, garlic, and milk (Table 7). Beside these vegetables, farmers of Kalapani CFUG also sold chilly, squash, young shoot of squash and pumpkin, egg plants, and sponge guards. Agroforestry products were distributed through a chain of producer, agriculture cooperatives/local collectors, wholesaler, retailers and consumers.

Two co-operatives (Paribartanshil Multi Purpose Co-operative and District Micro Enterprise Association) are under operations for the marketing of agroforestry products in Dhungkharka VDC. Figure 5 shows the agroforestry products marketing mechanisms of Dhungkharka site.

Producers

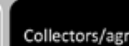
Coliectors/agti-
cooperative Wholesallers Retailers Consumers Consumers corse
According to the wholesalers of Kalimati (located at Kathmandu), fruits and vegetable wholesale market, vegetable grown in Dhungkharka were in high demand in Kathmandu Metropolitan City compared with vegetables grown in low lying areas of Kavrepalanchok, Nuwakot and Dhading districts because farmers of Dhungkharka had grown vegetables following the Integrated Pest Management (IPM) techniques supported by the different government organizations and I/NGOs. Milk was marketed using the chilling centre located in Parthali Bhanjyang.

The production capacity of traded agroforestry products of Dhungkharka site has been increased in recent years with increasing trend in number of farmers, land areas, per unit production and price of agroforestry products compared with three years ago (Table 7) shows that farmers of Dhungkharka are obtaining reasonably high price compared with the farmers of other sites. This is due to the well organized vegetable collection and marketing mechanisms developed by the local peoples.

Farmers of Dhungkharka had used urea and potash, vitamins and fungicides in vegetable farms. The use of chemical fertilizers ranged from 25-50 kg per household, which cost Rs 50 per $\mathrm{kg}$. The average cost of production of potato and tomato was about Rs 21 per $\mathrm{kg}$, and cauliflower and cabbage was Rs 13 per $\mathrm{kg}$. The transportation cost of these products was about Rs 4 per $\mathrm{kg}$ from Dhungkharka to Kathmandu.

Fig. 5: Market chain of agroforestry products of Dhungkharka test site

Table 7: Agro forestry products, their quantity and per unit price at different markets

\begin{tabular}{|l|l|l|l|l|}
\hline \multirow{2}{*}{$\begin{array}{l}\text { Agroforestry } \\
\text { products }\end{array}$} & \multirow{2}{*}{$\begin{array}{l}\text { Approximate } \\
\text { quantity }\end{array}$} & \multicolumn{3}{|l|}{ Price (Rs/kg) (Rs/ litre) at different level of markets } \\
\cline { 3 - 5 } & Farm gate (Local) & District & National \\
\hline Tomato & $27,000 \mathrm{~kg}$ & 30 & 40 & 55 \\
\hline Cabbage & $180,000 \mathrm{~kg}$ & 20 & 30 & 45 \\
\hline Cauliflower & $12,000 \mathrm{~kg}$ & 20 & 35 & 50 \\
\hline Potato & $60,000 \mathrm{~kg}$ & 30 & 45 & 55 \\
\hline Mustard leaves & $12,000 \mathrm{~kg}$ & 15 & 25 & 30 \\
\hline Radish & $9,000 \mathrm{~kg}$ & 15 & 30 & 35 \\
\hline Garlic & $4,500 \mathrm{~kg}$ & 60 & 75 & 90 \\
\hline Milk & 2500 litre/day & $70 /$ litre with 6\% fat & $\begin{array}{l}65 / \text { litre after butter } \\
\text { extraction }\end{array}$ & $\begin{array}{l}65 / \text { litre after } \\
\text { butter extraction }\end{array}$ \\
\hline
\end{tabular}




\section{Phagarkhola CFUG Chaubas, Kavre}

The main agroforestry products grown and marketed from Chaubas site were cardamom, pumpkin, lapsi fruit, and the forest products from pine and utis trees. These products were traded through producers to consumers via local traders/collectors and retailers. Generally, farmers produce vegetables and other products in small quantity, and therefore, these products are collected by collectors or local traders in one place through a group of farmers or cooperatives and delivered to the city in retail shops. Retailers of Kathmandu valley and Banepa purchase agroforestry products from the traders of Chaubas and sell to the end users at a marked up price.

Cardamom and timber were the main products which were normally sold to contractor of Kathmandu through farmer's cooperative with initiative of LRP members and local traders. The Chaubas Multipurpose Co-operative which has 600 members is working to support in marketing of cardamom and other agriculture products. Figure 6 shows the agroforestry products marketing mechanisms of Chaubas site.

Timber brought from Chaubas is normally used to make furniture through which value in timber is added by nearly $40 \%$ compared with sawn timber sold in the market.

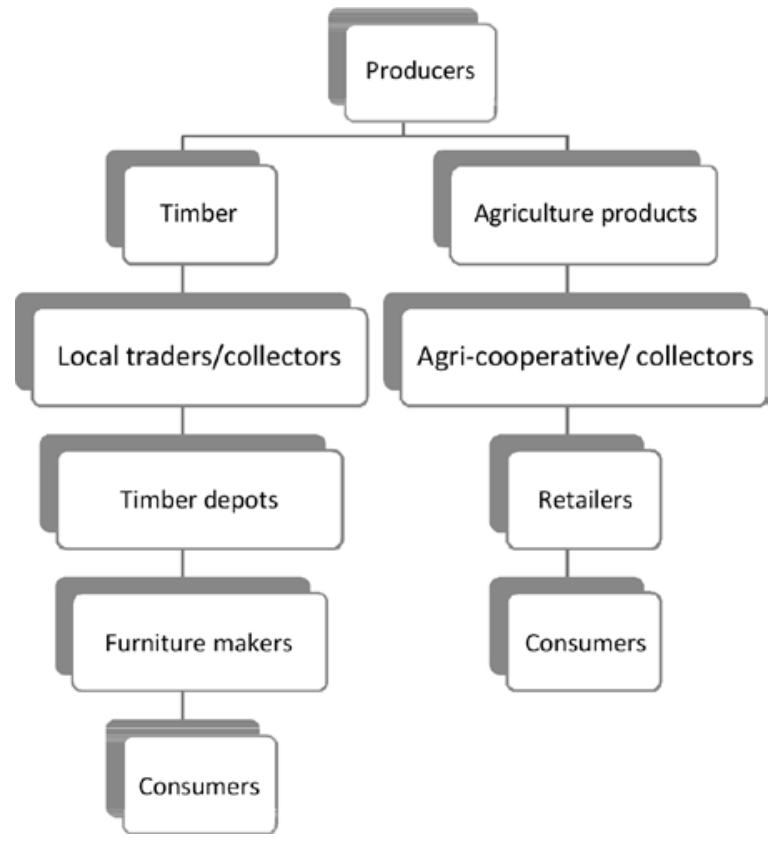

Fig. 6: Market channels of agroforestry products of Chaubas test site

The production of marketed agroforestry products of Chaubas site has been increasing in recent years with increasing trend in number of farmers, land areas, per unit production and price of agroforestry products compared with three years ago (Table 8) shows the large variation in price of pine timber in Kathmandu market, which is normally determined by the size of sawn timber. Pine timber obtained from plantation forests was small in size and were sold at the rate of Rs 800/

Table 8: Agroforestry products, their quantity and per unit price at different markets

\begin{tabular}{|l|l|l|l|l|}
\hline \multirow{2}{*}{$\begin{array}{l}\text { Agroforestry } \\
\text { products }\end{array}$} & \multirow{2}{*}{$\begin{array}{l}\text { Approximate } \\
\text { quantity }\end{array}$} & \multicolumn{3}{|l|}{ Price (Rs/unit) at different level of markets } \\
\cline { 3 - 5 } & & Farm gate (Local) & District & National \\
\hline Cardamom & $1000 \mathrm{~kg}$ & $2200 / \mathrm{kg}$ & $2200 / \mathrm{kg}$ & $2400 / \mathrm{kg}$ \\
\hline Pumpkin & $20,000 \mathrm{~kg}$ & $5 / \mathrm{kg}$ & $25 / \mathrm{kg}$ & $35 / \mathrm{kg}$ \\
\hline $\begin{array}{l}\text { Marigold } \\
\text { flower }\end{array}$ & 20,000 Garland & $50 /$ Garland & $60 /$ Garland & $70 /$ Garland \\
\hline Lapsi & $2,500 \mathrm{~kg}$ & $15 / \mathrm{kg}$ & & $35 / \mathrm{kg}$ \\
\hline Utis timber & $3,000 \mathrm{cft}$ & $200 / \mathrm{cubic}$ feet $(\mathrm{cft})$ & $400-450 / \mathrm{cft}$ & $500 / \mathrm{cft}$ \\
\hline Pine timber & $2,000 \mathrm{cft}$ & $300 / \mathrm{cft}$ & $600-800 / \mathrm{cft}$ & $800-1400 / \mathrm{cft}$ \\
\hline
\end{tabular}

Note: One cubic meter is approximately 35 cubic feet. 
Table 9: Name of saving and credit groups and their annual interest rate

\begin{tabular}{|l|l|l|l|l|}
\hline S.N. & District & Study sites & \multicolumn{1}{|c|}{ Name of Saving and credit Groups } & \multicolumn{1}{|c|}{$\begin{array}{c}\text { Interest rate } \\
\text { (\%) }\end{array}$} \\
\hline 1 & Kavre & Methinkot & $\begin{array}{l}\text { Methinkot saving and credit cooperative, } \\
\text { Jorsalla Agri-seed production cooperative } \\
\text { and Panchakanya Agri- } \\
\text { coperative }\end{array}$ & $14 \%$ per year \\
\cline { 3 - 5 } & Dhungkharka & $\begin{array}{l}\text { Nari Chetana saving and credit } \\
\text { cooperative, Bindabasini saving and credit } \\
\text { cooperative and Parbati saving and credit } \\
\text { cooperative, etc. }\end{array}$ & $14-16 \%$ per year \\
\cline { 3 - 5 } & Lhaubas & $\begin{array}{l}\text { Agri-saving and credit group and } \\
\text { Chaubas multipurpose cooperative }\end{array}$ & $\begin{array}{l}14 \% \text { per year } \\
15 \% \text { per year }\end{array}$ \\
\hline \multirow{2}{*}{2} & Lamjung & Dhamilikuwa & $\begin{array}{l}\text { Champabati saving and credit } \\
\text { cooperative }\end{array}$ & $15 \%$ per year \\
\cline { 3 - 5 } & Jeeta Taksar & Deep Jyoti cooperative & $8 \%$ per year \\
\cline { 3 - 5 } & Nalma & Sunkot saving and credit cooperative & $18 \%$ per year \\
\hline
\end{tabular}

cft in Kathmandu market. Additionally, farmers of the Chaubas had obtained low price for pumpkin compared with other agroforestry products. Until now, farmers of Chaubas have no problems to sale their products because local traders and Chaubas Multipurpose cooperative members have good linkage with district and national level traders of Kathmandu valley.

Farmers of Chaubas site had used chemical fertilizers (urea) in maize and millet production only which cost Rs 46 per $\mathrm{kg}$. The transportation cost of agriculture products from Chaubas to Banepa was about Rs 8-10 per kg depending on season.

\section{Analysis of results}

\section{Provision of funds}

In all sites, there were provision of fund at specific interest rate for the promotion of agriculture, livestock and off-farm enterprises through local saving and credit groups and cooperatives (see Table 9). Both men and women are eligible for loan, which is provided with the recommendation by one of their committee member for one year. CHOICE Nepal- a local NGO working in Jeeta Taksar had provided Rs 200,000 as a loan to Deep Jyoti Cooperative for goat and poultry farming.
The maximum limit of loan is Rs 100,000 per person per year at $8 \%$ interest rate.

In Nalma, very few persons had taken loan for agriculture purposes, and majority $(90 \%)$ of the loan was for foreign job. In Dhungkharka site farmers had not taken loan for vegetable production. On the other hand, most household women and men have saved small amount (Rs $25 /$ month) in these saving and credit groups.

\section{Institutions supporting farmers}

Different institutions are supporting LRP and LRG members for agroforestry products promotion and marketing. Agriculture Service Centre and Public Awareness Centre of Dhamilikuwa had provided training to the LRP and LRP members in cash crop production and marketing. Similarly, CHOICE, Nepal had provided about two million rupees in Deep Jyoti Cooperative in JeetaTaksar. Table 10 shows the local and district level institutions supporting farmers for agroforestry production and market chain development and management in six research sites. 
Table 10: Institutions supporting agroforestry farmers

\begin{tabular}{|l|l|l|}
\hline \multirow{2}{*}{ District } & \multicolumn{2}{|c|}{ Institution } \\
\cline { 2 - 3 } & \multicolumn{1}{|c|}{ Local level } & \multicolumn{1}{|c|}{ District level } \\
\hline Kavrepalanchok & $\begin{array}{l}\text { CFUG, Farmer's cooperative, } \\
\text { Ilaka Forest Office and } \\
\text { Agriculture and Livestock } \\
\text { Service } \\
\text { Centre, Village Development } \\
\text { Committee (VDC) and } \\
\text { Municipality, etc. }\end{array}$ & $\begin{array}{l}\text { District Forest Office (DFO), Federation of } \\
\text { Community Forest User, Nepal (FECOFUN), } \\
\text { District Agriculture Development Office } \\
\text { (DADO), District Livestock Service Office } \\
\text { (DLSO), District Soil Conservation Office } \\
\text { (DSCO) and District Development } \\
\text { Committee (DDC). }\end{array}$ \\
\hline \multirow{2}{*}{ Lamjung } & $\begin{array}{l}\text { CFUG, Farmer's cooperative, } \\
\text { CHOICE Nepal, Saving and } \\
\text { credit group and Mother } \\
\text { groups, } \\
\text { Ilaka Forest Office, } \\
\text { Agriculture and Livestock } \\
\text { Service Centre, } \\
\text { Public Awareness Centre and } \\
\text { Municipality, etc. }\end{array}$ & $\begin{array}{l}\text { DDC, Federation of Ethnic Groups, District } \\
\text { Irrigation Office and Micro-Enterprise } \\
\text { Development Programme of the United } \\
\text { Nations. }\end{array}$ \\
\hline
\end{tabular}

The Micro-Enterprise Development Programme (MEDEP) of the United Nations had also provided support for vegetables production and marketing in Dhungkharka and cardamom production and marketing in Chaubas site. Similarly, LRP and LRG members of Chaubas site had also received financial support from the Chaubas Village Development Committee for agroforestry production and marketing. Majority $(86 \%)$ of the total respondents had reported that training and cross-visit opportunities provided by the Enhancing livelihoods and food security through improved agroforestry and community forestry in Nepal (EnLiFT) project had also played significant roles in promoting agroforestry activities in the respective research sites.

\section{Gender and social inclusion}

The involvement of women in agroforestry products promotion and marketing was very high in Chaubas and Dhungkharka sites with more than $75 \%$ participation of women followed by nearly $50 \%$ in Dhamilikuwa, Methinkot and Nalma and $42 \%$ in Jeeta Taksar. The involvement of Dalit and marginalized households in agroforestry production and marketing in study sites was low (nearly $10 \%$ ) because they had very small land holding to produce agroforestry products. In addition, they were forced to work as wage labour for day to day survival of their family members.
The involvement of ethnic communities such as Gurung, Tamang, Magar, Bhujel and Pahari was higher (50\%) compared with the involvement of Brahmin and Chhetri (40\%).

\section{Issues and constraints of marketing}

Agroforestry marketing mechanism is very good in Dhungkharka site compared with other sites. The major issue for developing well organized marketing system in all sites was small scale production. In addition, LRP and LRG members of Jeeta Taksar are facing problems to sell ginger. The involvement of Dalit and marginalized community in agroforestry products market chain is very poor. The main issues and constraints of market chain of all agroforestry products are discussed below:

The major strengths for agroforestry products promotion and marketing in study areas are because of relatively good road network, nearness to market, and good access of services of local and district level institutions, fertile land, long tradition in growing fruits, vegetables and other cash crops, active women and supporting farmers. However, the major constraints noted for agroforestry products marketing are small scale production, small number of local traders, occurrence of insects (aphids, white grub, red ant, etc), pests and diseases (damping off) and lack of 
common facilities for marketing of agroforestry products. In addition, capacity of local institutions such as farmer's cooperatives, saving and credit institutions and mother groups are low to promote marketing of agroforestry products.

The major limitation reported by the LRP and LRG members for the promotion of agroforestry products marketing is the out migration of youth in search of better opportunities.

\section{Expectation of market chain changes}

In Jeeta Taksar and Dhamilikuwa sites, the number of farmers, land areas and per unit agriculture production have been increased compared to last three years. The main factors responsible for increased agroforestry production are rise in awareness level, and effective communication. Additionally, farmers are more inclined to cash crops because of the attractive price of agroforestry products except in Nalma, the marketing situation of agroforestry products was found different where the price of potato has been increased by $50 \%$ compared to the last three years ago. This was attributed to the increase of potato price in Besisahar vegetable markets. Other factors responsible for increase in price of agroforestry products in Nalma were low production compared with local demand and problem of irrigation to increase the production price.

Similarly, the number of farmers, land areas and per unit agriculture production has also been increased in Chaubas and Dhungkharka sites compared with the last three years. The main factors responsible for this change were increase in demand, improvement in transportation facilities, increase in production, commercialization, mass production trend in village, market information flow, and skill and technology handover through training and field visit programs to farmers. In addition, market price of vegetables and milk in Dhungkarka has also increased by $30 \%$ compared with the last three years. Similarly, market price of cardamom, lapsi and marigold flower in Chaubas has been increased by $40 \%, 15 \%$ and $20 \%$ respectively compared to the last three years.

Agroforestry production in Methinkot site has been found negative as compared to the last three years. This is because of change in rainfall pattern, lack of irrigation facilities, reduction in per unit production.

The expectation of market chain changes of agroforestry products over the next five years shows that round chilly, banana, black pepper, tomato, potato, onion, ginger, turmeric and lapsi would increase and local cooperatives would come into picture for marketing. It is found that future agroforestry practices would be driven by only children and aged persons, as youth are leaving their village in search of better opportunities. In case of Kavre site it is expected that the production of selected items such as cardamom, marigold flower, ginger and tomato and other vegetables would increase and more farmers would be involved for commercialization of these products with strong network of farmers established and function in place. Price of cardamom will increase from Rs $2200 / \mathrm{kg}$ to Rs $3500 / \mathrm{kg}$ as with the labour cost (by $75 \%$ from Rs 350/day).

\section{Conclusion}

The analysis shows that 14 agroforestry products in Lamjung and 20 agroforestry products in Kavrepalanchok are being marketed. LRP and LRG members involved in these agroforestry products marketing in Lamjung district have good connection with local traders, fruits and vegetables shop keepers whereas LRG members of Kavrepalanchok district have good linkage with local collectors and wholesalers of the Kathmandu valley. Farmers of all sites are obtaining good price for their products. However, two critical factors controlling the effectiveness and efficiency of agroforestry marketing were: a) scale and b) service. Small-scale production and insufficient service to farmers from the village level agriculture collection centers and cooperatives are the major constraints for effective and efficient market chain development and management of full range of agroforestry projects. The number of farmers, land areas under agroforestry practices and per unit agriculture production and price of agroforestry products has also been increased compared to the last three years. The main factors responsible for increasing agroforestry production in research sites are the rise in the level of awareness among LRPs/ LRGs in agroforestry practices along with institution being empowered in their functioning. 


\section{Acknowledgements}

We are grateful to EnLift project for providing us the opportunity of carrying out this study.We would also like to thank all the local resource persons and local resource groups for their active participation in the study.

\section{References}

Amatya S. M., Nuberg, I., Cedamon, E., and Pandit, B. H. 2015. Removing barriers to the commercialization of agroforestry trees in Nepal. In Small-scale and Community Forestry and the Changing Nature of Forest Landscapes, Sunshine, Australia, 2015.pp 5-17

Hair, J. F., Wolfinbarger, M. F., Ortinau, D. J. and Bush, R.P. 2010. Essentials of Marketing Research. 2nd edition. McGraw-Hill, New York, USA.

ILO. 2000. Rapid Market Appraisal: A Manual for Entrepreneurs. The FIT Manual Series. International Labour Organization, Geneva.

NAF. 2014. Identification and Listing of Researchable Agroforestry Products Market Opportunities in Six Sites of Lamjung and Kavre districts of Nepal. A report submitted to ACIAR/EnLiFT project.
Ostertag, C., Lundy, M., Gottret, M.V., Best, R. and Ferris, S. 2007. Identifying Market Opportunities for Rural Smallholder Producers. Rural Agro-enterprise Development Project, Centro International de Agriculture Tropical, Palmira, Colombia.

Pandit, B. H., Ojha, H., Shrestha, K. K., Nuberg, I. and Amatya, S.M. 2014. "Why Cannot Local Communities Do Forestry Business? Analysis of Barriers in the Value Chain of Private Forestry Products in Nepal" paper presented at the Sixth National Community Forestry Conference, June 16-18, 2014, Kathmandu, Nepal.

Perdana, A., Budidarsono, S., Kurniawan, I. and Roshetko, J. M. 2013. Rapid market appraisal. In Negotiation-support tool kit for learning landscapes (eds.) Van Noordwijk, M., Lusiana, B., Leimona, B. and Wulandari, D., World Agroforesry Centre (ICRAF) South East Asia Regional Program. 